\title{
ENHANCING PUBLIC SERVICE ETHICS IN INDONESIA: COMBATING CORRUPTION AND BUILDING INTEGRITY IN THE PUBLIC SECTOR
}

\author{
I Gede Eko Putra Sri Sentanu* \\ Faculty of Administrative Science, University of Brawijaya, Indonesia
}

Cyntia Keliat, Tri Utami Handayani

College of Public Administration, Huazhong University of Science and Technology, China

\author{
*E-mail: sentanu@ub.ac.id
}

\begin{abstract}
Corruption is one of the biggest problems faced by Indonesia and brings the impact which not only harms the finances of the state, but also a violation of the rights to social and economic society, undermining democracy and welfare, rule of law and postpones construction. Efforts to combat corruption have been conducted in Indonesia. Nevertheless, the various attempts tend to be still done partially and do not have a clear strategy. Various efforts are not able to reduce significantly the magnitude of criminal acts of corruption that occur in Indonesia. This paper tries to deliberate about the concept and meaning of the importance of public service ethics, and the eradication of corruption, its implications for the ethics of the public service in Indonesia. Public ethics play an important role in improving public services so that people can be served well and the construction can be run in accordance with its objectives based on principles of good governance.
\end{abstract}

\section{KEY WORDS}

Public service, integrity, corruption, public sector, ethics.

The issue of ethics in the public service in Indonesia less widely discussed. Ethics is often seen as an element that is less concerned with the world of public service. Whereas, in the literature on public services and public administration, ethics is one of the elements that determine public satisfaction is a successful organization. These elements must be considered in every phase of public services ranging from policy formulation, service design, the organizational structure of the service management to achieve the goal. In the public service, the act violates the moral or ethical difficult traced and questioned due to the habit of Indonesian's society prohibits people "open secrets" or threaten those who complained. Meanwhile, we also face the challenges of the future are increasingly heavy because of ethical assessment standard of service continues to change according to the development paradigm. And substantively, we also have not reached the maturity and autonomy is ethical because it is full of dilemmas. Corruption is rife in Indonesia that occurred in the public service sector, by lengthening the process of public service. Therefore, if the service can be provided in a timely manner so the public does not need to play with things that could culminate in the act of corruption. There are at least three standard services, i.e., time, speed, and cost. Standard service is a measure enacted in implementing mandatory service adhered to by the provider and the recipient of public service.

Corruption extremely has injured the public confidence, which is a public ethics is not running properly, with basic obedience as part of integrity and responsibility to the public. The ethics of public administration is the rule or standard management, moral direction to members of the organization or the job management; the rules or standards of management which are a moral direction for the public administrator in performing his task of serving the community. The precast authorization settings could lead to corruption when an official has the authority to do monopolistic arrangements and authorization without the balanced availability of transparency, clarity of procedures and administrative efforts. 
The Corruption Perception Index in 2014, Indonesia ranked 117 out of 175 countries in the world with a score of 34 on a scale of 0-100 (0 means very corrupt and 100 means very clean). Data also revealed that corruption is the top ranks of 18 (eighteen) factors restricting the ease of trying in Indonesia (Thohary, Suyatmiko, Yazid, \& Ratnaningtyas, 2015). Up to semester 1 in year 2016, the performance of an investigation of law enforcement officers managed to raise the status of the investigation into the case from the investigation as much as 210 cases, where the State's losses reached RP 890.5 billion and IDR 28 billion bribes, SGD 1.6 million, and USD 72 thousand, with the number of the suspect as many as 500 people (ICW, 2016).

Ethics deals with how a human behavior that can be justified. In carrying out the tasks in the public administration, then an administrator should have a responsibility to the public. This paper tries to deliberate about the concept and meaning of the importance of public service ethics, and the eradication of corruption, its implications for the ethics of the public service in Indonesia.

\section{CONCEPTUAL PERSPECTIVE: ETHICS AND PUBLIC ADMINISTRATION}

The term "ethics" comes from the Greek word 'ethos', which means "character" and ethics deals with the moral behavior in humans and how one should act. Amundsen \& Andrade $(2009$, p.6) argued that ethics is continuous effort to ensure that people and institutions have been established, in accordance with appropriate standards and reasonable, and solidly-based. Ethics can also be defined as the philosophy and professional standards (rules of right conduct) that should be followed by the providers of public services and public administration.

Public ethics emerged from the concerns against the public service is bad because of the conflict of interest and corruption. Numerous attempts at repair the bureaucracy and political organizations have been carried out. The commissions were formed, officials replaced, but corruption failed to recede and public services to deteriorate. When the reconstruction of bureaucracy and tightening supervision done but still rampant corruption, it shows that the error is in the system of the organization itself. The crucial thing that needs to be done is to change the system of organization of public ethics by integrating into the organization of the public service. Public ethics not only emphasize the ethical codes or norms but also the reflective dimension. The public ethics will help the officials and politicians in considering public policy choices, and evaluation tools that take into account the ethical consequences. Therefore, the focus is directed at the ethical modality, namely how to bridge the gap between norms of moral and factual actions. Ethics is closely related to the public administration. Learn about the philosophy of ethics, moral values, and whereas the public administration learning about making policy, decision-making, and implementation of the policy. Ethics are abstract, and with regard to the question of good and bad, while the administration is both concrete and must realize what has been formulated and agreed upon in public policies. Talk of ethics in public administration is how to associate the two questions, how the ideas of the administration, such as effectiveness, efficiency, accountability, productivity, expediency can explain the ethics in practice, and how the basic ideas of ethics, as it embodies the good and avoid the bad ones, can explain the nature of public administration. So, expect a public administrator always uses the consideration of ethics in conducting all activities relating to the public interest. The ethics of public administration as a part of social ethics have a relationship that is very close with the ethics of the profession, political ethics, environmental ethics, family ethics, and attitude towards fellow even against criticism of an ideology, as illustrated in Figure 1.

The Figure 1 shows that an official, in carrying out his position as the public administrator must have at least a good family ethics. Even the attitude towards fellow also determines the sense of respect society because he became a mirror and model for a wider audience. In the chart indicated that the ethics of public administration between the ethics of the profession and political ethics. Assuming an administrator is a person who must apply the science of management and organization in a professional manner. They should be able to 
solve tactical problems well and able to manage the Organization efficiently, as well as the responsibility to the society's extensive and diverse. To that end, the administrator is required to have a high sensitivity to the problem of politics.

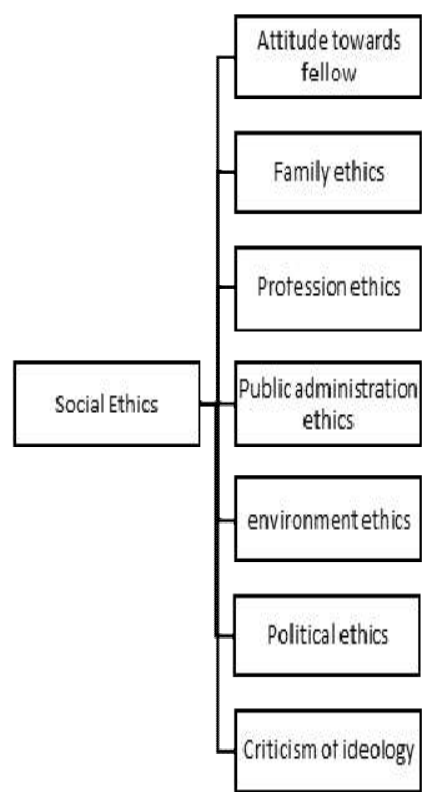

Figure 1 - The Ethics of Public Administration as a part of social ethics (Source: Kumorotomo, 1992)

Ethical values should be used as a reference for the public bureaucracy in behaving to provide services to the public, as well as a standard for assessing whether the behavior and services it provides are judged to be good or bad by the public. In order to guarantee performance standards and to minimize the abuse of power by public officials, the accountability of service ethics becomes an obligation. Some value considerations in public ethics, among others effectiveness-efficiency, accountability, quality of service and responsiveness.

Public service ethics is a serious issue in public sector (Radhika, 2012). Deviation from normal standards of ethics takes various forms of corruption in the civil service (Kim, Monem, \& Baniamin, 2013, p.99). Corruption is rampant in many countries, in many aspects of life (Tanzi, 1998; Pathak, Belwal, Naz, \& Smith, 2008; Chêne, 2012). Corruption is like a disease that has already spread, dangerous and causes of addiction for the culprit. Most of the problems in public administration in different countries are derived from corruption. (Kim, Monem, \& Baniamin, 2013, p.99).

Tanzi $(1997$, p.8) stated that "Corruption is the intentional non-compliance with the arms-length principle aimed at deriving some advantage for oneself or for related individuals from this behavior. Liu (1983, p. 603, cited in Dong, 2011, p.12) thus differentiates between three types of corruption: "corrupt acts such as embezzlement and bribes, which are commonplace among nations having a political system to speak of; ... appropriation of public goods, illegal trade, and housing irregularity, [which result] from a breakdown in the central allocation system and [are] commonplace among socialist nations ... [and the] rather peculiarly Chinese Communist [practices of] illegitimate feasting, feudal rites, false models, and illegal imprisonment and torture".

Corruption is a crime that is ethically highly inappropriate and embarrassing, the corruptor was supposed to get moral and legal sanctions. Akinseye (2000) attempts at describing it as 'mother of all crimes' and identifies four forms of corruption as bribery, graft, and nepotism. So, in the study of the literature of public administration has been called for to improve the level of ethics in the public service, and setup of the highest level of ethics in the reform agenda. 
Corruption generally occurs because of the abuse of authority, power, lack of accountability and transparency, misuse of public resources and exploiting a conflict of interest (May 2012; Peace, 2010; Martini, 2012; Olken \& Pande, 2012; Neang, 2010). According to Goolsarran (2006, p.61), corruption causes a number of impacts on the economy, namely: (1) goods and services become more costly to the detriment of the quality and standard of life of the community; (2) trade is distorted because the preference is more given to goods and services which can offer a high level of bribery; 3) accumulation of longterm public debt levels are high due to the tendency of corrupt Governments, to use the loan funds from overseas to finance capital-intensive projects; and (4) miss-allocation of scarce resources and regional imbalances because of the mentality of a corrupt government officials more concerned with areas that can provide advantages for himself.

Kim, Monem, \& Baniamin (2013, pp.100-103) in their research report, entitled Enhancing Public Service Ethics in Bangladesh: Dilemmas and Deterrents, explained that corruption is an action that deviates from the standard behavior. It is then described two key variables for the ethics of the Organization, namely: Level of Individual ethics and Level of Organizational Ethics. By combining both of these variables, which are named with an Ethical Grid for an organization. The attributes of these variables have different levels of effect on the controlling of corruption in an organization.

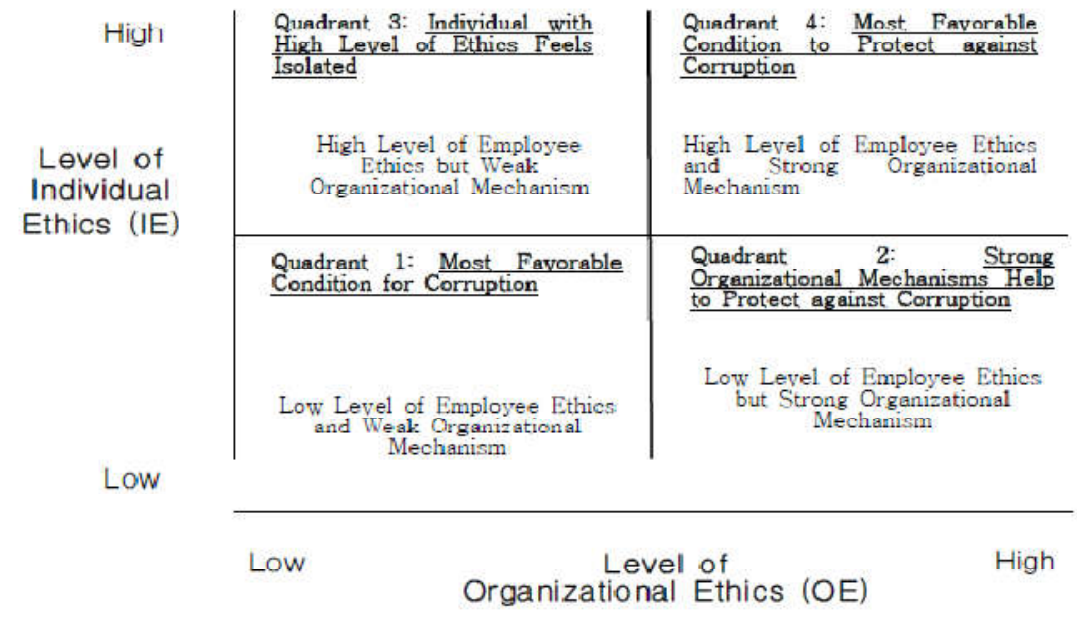

Figure 2 - Ethical Grid for an Organization (Source: Kim, Monem \& Baniamin, 2013)

Each quadrant describes the position of the individual and organizational level of ethics to an organization. In quadrant 1 , an employee of individually has a tendency to do corruption because of the low level of ethics. In quadrant 2, individual ethics is low but organizational ethics is high. The ability of ethics of the Organization in creating a system of accountability and transparency can suppress occurrence of corruption by individual employees. In quadrant 3, individual ethics is high but organizational ethics is low, it means an individual employee with unethical activities can easily get away with minimal punishment, either with those who have a higher ethics. In quadrant 4 , both individual ethics and organizational ethics are high, corruption can be suppressed to very minimal limits by setting high ethical standards to the Organization, namely, the issue of ethics of individuals is also a problem of ethics organizations.

The importance of individual ethical standards set out in the Organization as an attempt to build a civilized and ethical culture in an organization and to bring influence to other individuals so they can suppress the occurrence of corruption. With the ethical standards expected public servants increasingly professional and was able to show that they can prioritize public services fairly and competing value added. However, the values on the standard of conduct that have been awakened in the quadrants that were presented above would be biased if then the power of ethics of individuals and of ethics of the Organization 
meet with the other powerful external forces, such as the business intervention, politics, the dynasty of political economy's interest, economic stress, socio-cultural, individual mentality in the education of families or even personal conscience.

Caiden (2000) was given the idea of public service professionalism which suggests a few things about the general benefits of it, namely: (1) Meeting an identifiable social need; (2) Questioning public sector utility; (3) Advancing universal human values; (4) Improving the quality of life; (5) Undertaking continuous legal, regulatory and administrative reforms; (6) Adopting more business like methods; (7) Enforcing the rule of law; (8) Following constitutionalism; (9) Expanding public policy-making capacity; and (10) Combating bureau pathologies.

Corruption has been breaking the boundaries of ethics and many other values, therefore the corruption must be eliminated. In the concept of public services, corruption is a chronic and systemic disease that may inhibit the user, damaging the image of the Organization and the public distrust. Public service involves the public trust, public ethics prerequisite and supporting public trust in realizing good governance (OECD, 2000). Citizens expect public servants can serve the public interest fairly and trustworthy. The sense of fairness in public service can inspire the public trust. The key to public trust in government is on people's satisfaction which is the performance, integrity, responsibility and the quality of services provided (Sentanu, 2015).

\section{CORRUPTION IN INDONESIA}

Indonesia has experienced a period of transition in the governmental system since the end of the authoritarian regime of General Suharto during 32 years in 1998. Indonesia has undergone a successful transition from authoritarian rule to one of the largest democracies country in Asia and in the world. During that transition, there were some major changes to the governmental system about the regional autonomy and decentralization. The local Government has more authority and power. A national campaign against corruption has been initiated after corruption was acknowledged as a major problem affecting the Indonesian economy, politics, and foreign investments. As explained above that corruption must be curbed immediately because it may cause a devastating systemic impact productivity, economic growth and social.

In the context of Indonesia corruption has caused at least two the main impact on the economy, including: (1) Corruption is a major barrier to economic growth and give a negative impact on investment and the growth of the private sector; (2) foster a negative sentiment, and the distrust of foreign investors. Corruption is not only detrimental to the finances of the State, but also a violation of the rights to social and economic society, undermining democracy and welfare, undermine the rule of law, and postpone construction.

Snape (1999, pp. 591-600), there are at least three (3) factors that have allegedly become because of growing Corruption, Collusion and Nepotism (KKN) in Indonesia, namely: (1) political factors; (2) economic factors; and (3) factors of Javanese culture. In the view of Snape, political factors are characterized by the existence of gaps in accountability, transparency, institutional democracy, and a free press is an important factor that contributed to the widespread corruption in Indonesia, especially in the communities of the old order era and the new order era. In the era of the new order, the condition of the government is one of the reasons corruption occurred make corruption in Indonesia become an institutional system. This institutional corrupted institution needs funding for sustainability. KKN practices that occur in the new order has its roots in the cultural traditions of the past that occurred in Indonesia, especially in a culture that is applied in Java. Related to this, an amount of practice of KKN rooted in ancient Java habit so it is regarded as something natural. These include cultural habits in giving gifts to the sovereign; loyalty to the family is more powerful compared to the State; as well as Javanese concept of power, hierarchy, and patrimony.

According to the Global Corruption Barometer (Transparency International, 2011), 43\% of households surveyed believe that the growth of corruption has increased in the three years preceding the survey. The Integrity Survey conducted by the Corruption Eradication 
Commission (KPK) showed an increase in the average value of public sector integrity from 5.53 in 2007 to 6.31 in 2011 (on a scale from 0, low integrity, to 10, high integrity) (KPK, 2011). Until the end of 2014, Indonesia is still experiencing a relatively high corruption.

Transparency International published an annual corruption perceptions index which assesses "the degree to which corruption is perceived to occur among public officials and politicians" in all countries throughout the world. The annual corruption perceptions index uses a scale from one to ten. The higher the result, the fewer corruptions happens. In the list of their latest by 2015, Indonesia was ranked 88 (out of a total of 175 countries). Nevertheless, it should be emphasized that there is no 100 percent accurate method to measure corruption because of the unique nature of corruption itself, that is often hidden away neatly. The Corruption Perception Index 2015 in the table below shows the level of perception of corruption by voters participating in the poll from certain countries. But because the public usually has a good understanding of what is happening in the country, these numbers indicate something fascinating and interesting things.

Table 1 - Corruption Perception Index 2015

\begin{tabular}{|c|c|c|}
\hline No & Country & Score \\
\hline 1. & Denmark & 9.1 \\
\hline 2. & Finland & 9.0 \\
\hline 3. & Sweden & 8.9 \\
\hline 4. & New Zealand & 8.8 \\
\hline 5. & Netherland & 8.7 \\
\hline 6. & Norway & 8.7 \\
\hline 88 & Indonesia & 3.6 \\
\hline
\end{tabular}

Source: Transparency International, 2015.

These numbers suggest that there is a common view that showing negative about the level of political corruption in Indonesia. However, when we consider the results before, corruption index showed a more positive trend.

Table 2 - Indonesia's Corruption Perception Index

\begin{tabular}{|c|c|c|c|c|c|c|c|c|c|c|c|}
\hline Year & 2005 & 2006 & 2007 & 2008 & 2009 & 2010 & 2011 & 2012 & 2013 & 2014 & 2015 \\
\hline Indonesia & 2.2 & 2.4 & 2.3 & 2.6 & 2.8 & 2.8 & 3.0 & 3.2 & 3.2 & 3.4 & 3.6 \\
\hline
\end{tabular}

Source: Transparency International, 2015.

These are a few charts that show the position of Indonesia in some different stages.

Table 3 - Indonesia's Position in Global Corruption Perception Index

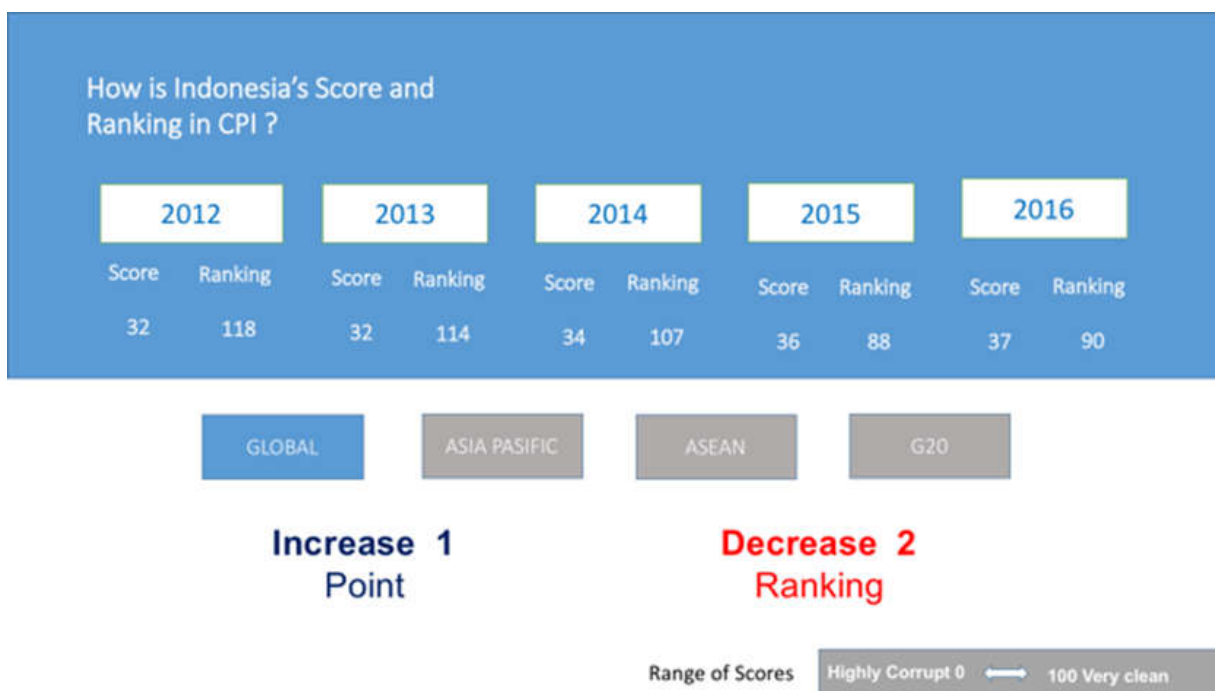

Source: Corruption Perception Index, 2016. 
In Global aspects, we can see the progress of Indonesia as one of the developing countries. Since 2012 until 2016 from the chart above showing that Indonesia increases 1 point in Corruption Perception Index in globally even though decreasing 2 points in ranking. That 1 point could be a very small step and achievement for Indonesia. that lower scoring shows that Indonesia faces the condition where there is a misappropriation of funds and many others problems.

Table 4 - Indonesia's Position in Asia - Pacific Corruption Perception Index

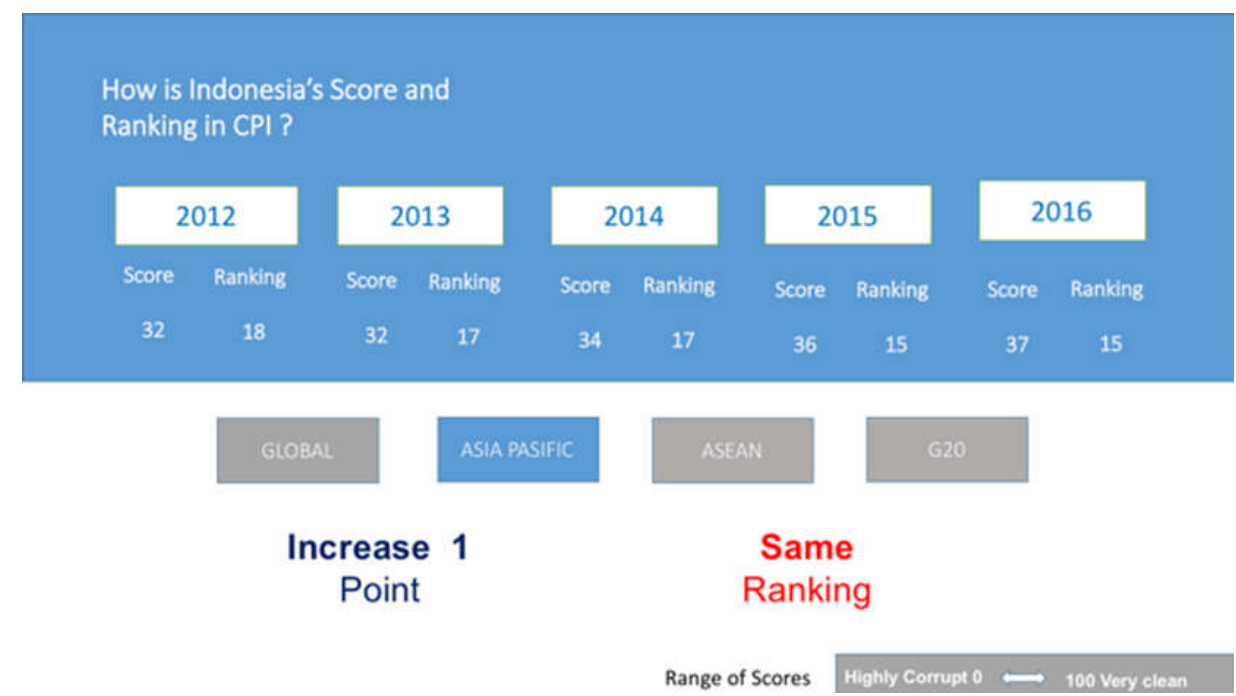

Source: Corruption Perception Index, 2016.

The majority of Asia Pacific countries sit in the bottom half of the Corruption Perception Index 2016, Indonesia one of those countries. This chart above shows that in Asia - Pacific category Indonesia increase 1 point and still at the same ranking in 5 years between 2012 2016. We can say that Indonesia as the democracy country might face the corruption problem because of lack of understanding about the democracy itself and also the number of uneducated people is still higher.

Table 5 - Indonesia's Position in ASEAN Corruption Perception Index

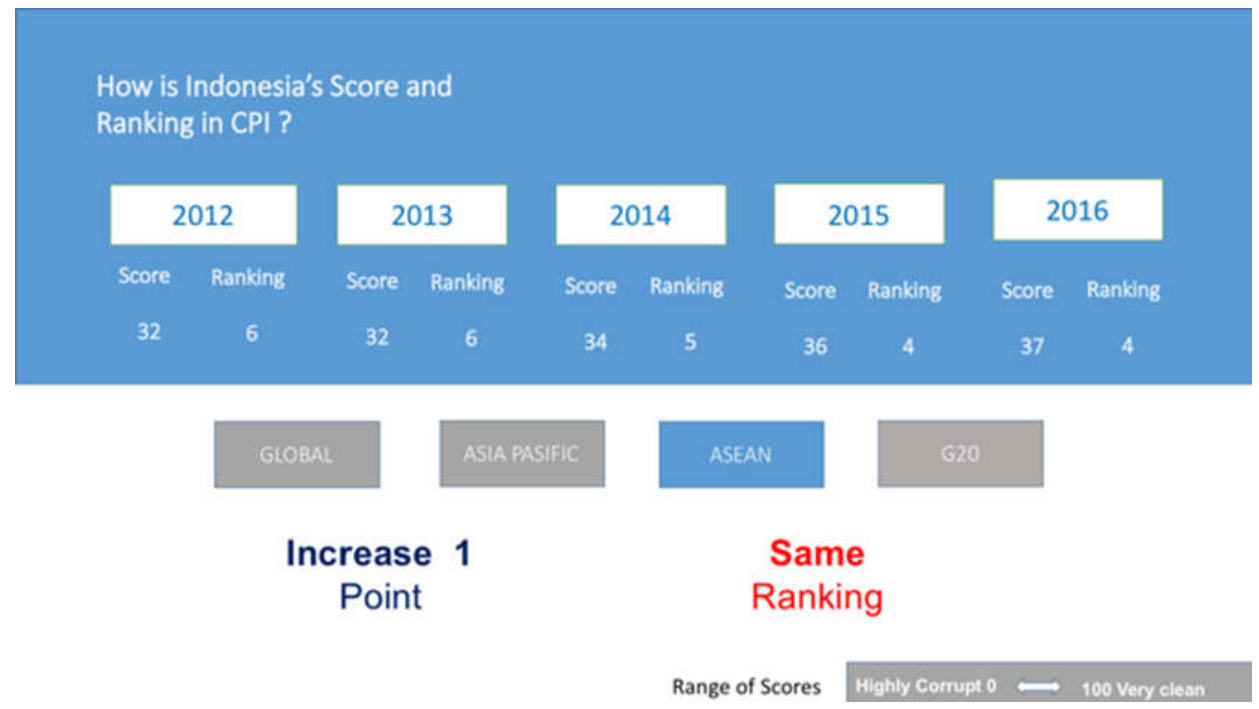

Source: Corruption Perception Index, 2016.

In ASEAN, Indonesia is in the position where an increase in one point but still in the same ranking in 5 years. Singapore is still in the first ranking among all nations in ASEAN. 
Table 6 - Indonesia's Position in ASEAN Corruption Perception Index

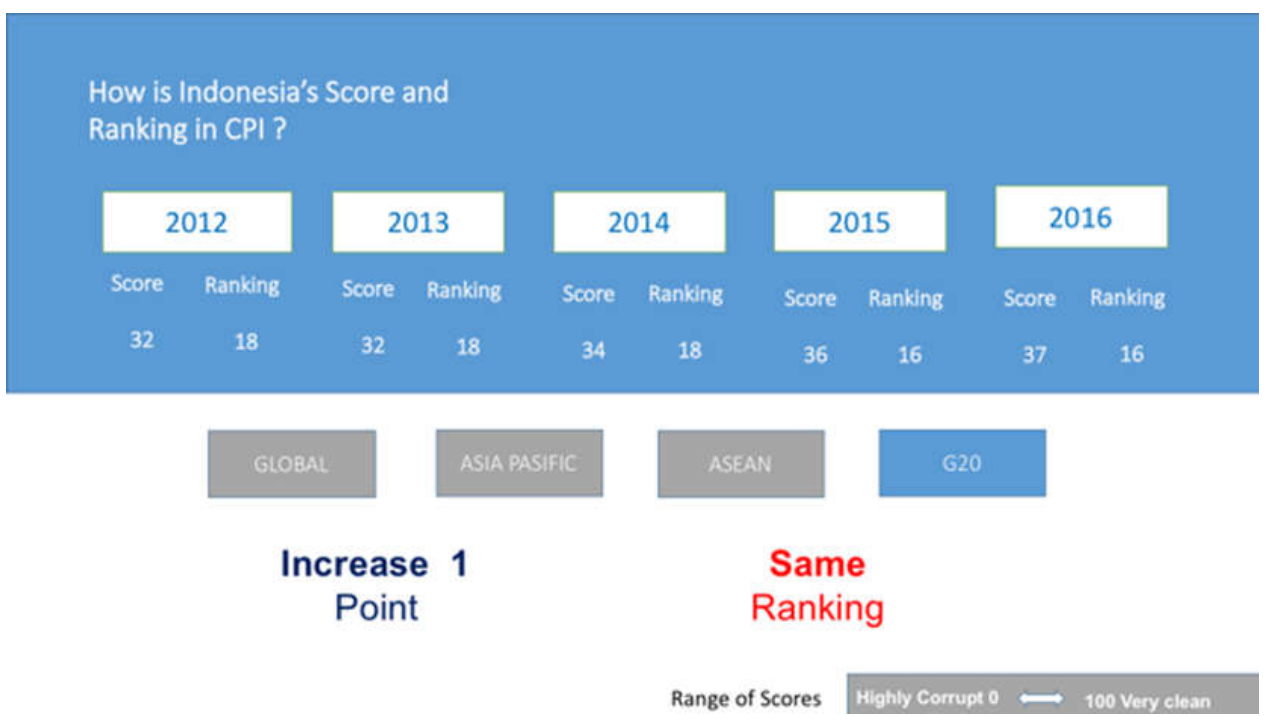

Source: Corruption Perception Index, 2016.

Indonesia is the one and the only member from south-east Asia and it is one of achievement according to Indonesia's government. In corruption perception index Indonesia has not passed the problem of corrupted and in-transparency bureaucracy almost in all aspects. In the period of 2005-2015 corruption in the terms of procurement of goods and services, this means that in many instances of corruption that happens in Indonesia is bureaucracy corruption. Corruption Eradication Commission (KPK) released as much as $77 \%$ of cases are cases relating to the procurement of goods and services. In recent years also identified that corruption transpired by political elites and political party members. Many politicians did not perform and functions as properly as they supposed to do, who do not perform tasks and functions properly. Many politicians who speak no manners so that sparked unrest in the community. In fact, not a few politicians who also get tangled in a legal case, that condition cannot be separated from the absence of binding legal rules regarding the code of ethics of politicians. During this time, the code of ethics of politicians only regulated by the internal party. The community cannot control. As many as 32 percents of cases handled KPK has involved politicians or party representatives.

\section{DISCUSSION OF POLICY IMPLICATIONS}

Speaking about continuing corruption in Indonesia, the impact continues into undermining the economy, the distribution of resources and public administration in Indonesia. All available data and reports pointed out that corruption is still widespread, absorbing all walks of life. The country ranks 115th out of 179 countries assessed and 23rd out of 41 countries in the Asia-Pacific region in terms of economic freedom. In particular, the country performed poorly in terms of freedom from corruption, with a score of 28 on a 0 to 100 scale. Corruption also seems to have penetrated to the local level according to Indonesia's Corruption Perceptions Index (Transparency International Indonesia, 2008). A majority of cities in the country score below the average of 4,42 (on a 0 , meaning more corrupt to 10, clean, scale). By 2015 Indonesia was in the 88 positions, Indonesia got the better perceptions index ranks increase by placing Indonesia on the order of 88 with better perceptions index.

There are some basic issues regarding the author's note, the reason why is corruption still occur and are likely to be systematic. First, the prevention system for corruption that is still not integrated into the enforcement law agencies like police, prosecutors, KPK, etc. Second, the punishment that meted out for corruptor doesn't give deterrent effect. Third, Corruption is not in the curriculum. Ethic's lesson that needs to be understood by the student 
from corruption did not apply as a priority at the neighborhood elementary school, middle and upper. Fourth, the influence of the political interests that involved in the educational system, and the very strong influence the course of the enforcement and the eradication of corruption in Indonesia; Fifth, ethics education at the basic level is not optimal implementation in people's lives as a result of the narrow understanding of reform towards democratic meaning is still less or not showing that it's supposed to be; Sixth, the low understanding of integrity and responsibility in the performance of the organization.

The fundamental reason public service should be given is the existence of a public interest Government responsibility. In providing these services, the Government is expected to implementing all the good governance them professionally and must take political decisions on who gets exactly in applying what, how much, where, when. Many cases prove that personal interests, family, group, party, and even a higher structure thus dictate the behavior of a bureaucrat or Government authorities. In this case, the bureaucrats do not have the "independence" in acting ethically, or in other words, there is no "ethical" in the autonomy.

Expenditure policy can cause corruption when there is a lack of transparency and oversight institutions effectively in policymaking on project investment, spending on procurement, as well as the determination of the extra-budgetary accounts. The financing of political parties and the quality of the bureaucracy can cause corruption when financing from the Government is not clear and the system of recruitment is more based upon political considerations, patron, and nepotism rather than merit as well as the absence of adequate rules regarding promotions and recruitment. For this reason, pay reform has been an important issue in public service management in Indonesia. A low poor level of salary, culture, a substandard of ethic's awareness is often used as the justification for corrupt practices by the civil servants.

As we can say that our government has been doing some practical ways to at least decrease the corruption itself. The government has been setting up the laws to decrease the corruption, such as statute book of the criminal law of Indonesia; law no.28 of 1999 on State Implementation of the Clean and Free of Corruption; Law no.31 of 1999 on Corruption Eradication, as amended by Act no. 20 of 2001; Law no. 30 of 2002 on The Establishment of the Corruption Eradication Commission; Presidential Regulation no. 55 of 2012 on The National Strategy Prevention and Combating Corruption of 2012 - 2025 for long-term planning and year of 2012-2014 for medium-term planning. It is also mentioned in the Article 5 of Law no. 28 of 1999 in the implementation of the state are free and clean from corruption and every operator state is obliged to free and commit to act free from corruption, collusion, and nepotism. Accordingly, each state apparatus must not be corrupt.

Furthermore, in Article 2 of Law no.31 of 1999 on Corruption Eradication, affirmed that:

1. Any person who knowingly acts unlawfully enrich themselves or another person or a corporation that can be detrimental to the State Finances and Economy, shall be detrimental to the State Finances and Economy, shall be punished with imprisonment for life imprisonment or imprisonment for a minimum of 4 (four) years and a maximum of 20 (twenty) years and a fine of at least Rp. 200,000,000.00 (two hundred million rupiahs) and Rp. 1,000,000,000.00 (one billion rupiah).

2. In the case of corruption as referred to paragraph (1) shall be done under certain circumstances, the death penalty can be imposed. Special materials to Law $\mathrm{np} .30$ of 2002, the following will be cited several articles which relate specifically to the handling of corruption that article 6, article 11 and article 13.

The government also creates an institution that specifically deals with corruption, called Corruption Eradication Commission (Komisi Pemberantasan Korupsi/KPK). There are 6 (six) national strategy focused activities in preventing and combating corruption, namely:

- Prevention;

- Law enforcement;

- Harmonization of legislation;

- International cooperation and rescue assets corruption proceeds;

- Education and culture of corruption; 
- The implementation of the reporting mechanism to eradicate corruption.

As the country that needs to fight corruption, there are instances that need to be done to facing a future challenge: government's consistency in the fight against the corruption; well-conducted coaching to all civil servants; make an agreement (the fact integrity) which must be signed by all the civil servants; all the civil servants are willing to declare their wealth every certain period (6 months or 12 months) over the internet/website.

In awarding the public service, especially in Indonesia, the moral and ethical violations can be observed starting from the public policy process (proposing programs, projects, and activities that are not based on fact), public service organization design (arrangement of the structure, formalization, dispersion of authority) which is very biased against certain interests, public service management process full of fabrications and camouflage (ranging from technical, planning, financial management, human resources, information, and so on). It can be showed from, all of it looked from the properties that are not transparent, unresponsive, unaccountable, and transparent.

The weakness implementation of the code of ethics presents to lead the public service to be disrupted. On that basis, the ethics are required in public administration. Ethics can be used as a guideline, references, instructions on what to do by the bureaucratic apparatus in the conduct of political policy, and it is used as a default judgment. We can see from it if the behavior of the bureaucracy officials in running political policy can be said to be good or bad. Ethics in the public service there is a set of values that can be used as citations, references, and guide for the public bureaucracy in carrying out its duties, namely: efficiency, impersonal, merit system, responsible, accountable, and responsiveness.

Public administration is making the important role in reducing the factor of corruption and bureaucracy is part of that public administration. Indonesia as one of the developing country is now facing all the constructions and progressing life to reach the standard to called as a developed country but we need to put consideration that there's the reason why we still called as a developing country, especially in bureaucracy. Many of bureaucracy that exists is very complicated and intransparent. Intransparent means too many people involved in handling one problem/process. Beside intransparent, the other problem is also because all the data still in the manual process if the government could make it into digital/online maybe it can be reduced the problem that can cause corruption. This is what all the developing countries have done in all bureaucracy in all public administration sectors. As a developing country, we need to adopt good things from developing country and apply it to our case.

\section{CONCLUSION}

In practice of the public service currently in Indonesia, the provider must study the ethical norms as a guide to the vagaries of the Act. Any corruption of the powers delegated. The Corruptor is the people who gain power or authority of the enterprise or the State and use it for other interests. The increasing of public participation in public services in order to realize the transparency and accountability in the implementation of the service, develop a conception by establishing the participation of citizens in public service functions to build on creativity and community involvement in the development process.

Public accountability and public participation are instrumental that is considered able to overcome corruption criminal act both as a result of factors that are direct and indirect or resulting from factors that are derived from the individual and structural characteristics so that it can improve the quality of public services. Public accountability and public participation can also be correspondingly performed as a strategy that focuses both on the public, market, legal, or political. Implemented ethics in public administration is becoming a necessity for public administrators because of the ethics guidelines and serve as a reference for the public administrator in the exercise of those powers and duties, as well as the standard assessment of the behavior and actions of the public administrator. With good public administration ethics that have organizational culture and good management are expected to foster a culture of the Organization and management of good governance. 


\section{REFERENCES}

1. Thohary W., et.al., Survei Persepsi Korupsi 2015 (Jakarta, Transparency International Indonesia, 2015).

2. ICW., Kinerja Penanganan Kasus Korupsi Semester I 2016 (Jakarta, Indonesia Corruption Watch, 2016).

3. Kumorotomo W. Ethics of Public Administration (Jakarta:Rajawali Pers, 1992)123-125.

4. Amundsen, I., \& Andrade, V.P. Michelsen Institute (CMI)(Ed), Public Sector Ethics (Luanda, 2009)6.

5. Kim, Pan-Suk, Monem M, and Baniamin H.M, Enhancing Public Service Ethics in Bangladesh: Dilemma and Deterrents, 2013, 99.

6. Tanzi, V. (1998). Corruption Around the World: Causes, Consequences, Scope and Cures. Washington: IMF

7. Pathak, R. D. Singh, G., Belwal, R., Naz, R. \& Smith, R. F. I., E-governance, Corruption, and Public Service Delivery: A Comparative Study of Fiji and Ethiopia, JOAAG, Vol. 3. No.1, 2008

8. Liu, A. The Politics of Corruption in the People's Republic of China. American Political Science Review, 77, 602-623, cited in Dong, B. (2011, March). The Causes and Consequences of Corruption, master thesis., Queensland University of Technology, 1983.

9. May, A. M. (2012). Causes Corruption in The Public-Sector Institution and Its Impact on Development: Turning What We Know into What We Do.

10. Goolsarran, Swatantra Anand, Corruption: Its Nature, Causes and Effects Suggestions on the Way Forward, The Journal of Government Financial Management, Volume 55, No. 1, 2006.

11. Kim, P, -S., Monem, M., \& Baniamin, H. M., Enhancing Public Service Ethics in Bangladesh: Dilemmas and Deterrents, Michelsen Institute, 2013.

12. OECD. Trust in Governance: Ethics Measures in OECD Countries. Corruption in Developing Countries, Olken, B. A., \& Pande, R., (Paris: OECD, 2000).

13. Sentanu, I. G., Increasing Trust in Local Government Financial Management and Building Integrity: Efforts Reform in Indonesia. Public Policy and Administration Research, 2015, 5(3), 206-213.

14. Snape, Fiona Robertson., Corruption, Collution and Nepotism in Indonesia, Third World Quarterly, 1999, Vol. 20, No. 3. 